\title{
Imbalances Between the European Union and China
}

\author{
Kokko, Ari
}

Document Version

Final published version

Publication date:

2015

\section{License \\ CC BY-NC-ND}

Citation for published version (APA):

Kokko, A. (2015). Imbalances Between the European Union and China. Asia Research Centre. Copenhagen Business School. Copenhagen Discussion Papers No. 50

Link to publication in CBS Research Portal

\section{General rights}

Copyright and moral rights for the publications made accessible in the public portal are retained by the authors and/or other copyright owners and it is a condition of accessing publications that users recognise and abide by the legal requirements associated with these rights.

Take down policy

If you believe that this document breaches copyright please contact us (research.lib@cbs.dk) providing details, and we will remove access to the work immediately and investigate your claim. 


\section{June}

Imbalances between the European Union and China

Ari Kokko 
(C)opyright is held by the author or authors of each Discussion Paper.

Copenhagen Discussion Papers cannot be republished, reprinted, or reproduced in any format without the permission of the paper's author or authors.

Note: The views expressed in each paper are those of the author or authors of the paper. They do not represent the views of the Asia Research Centre or Copenhagen Business School.

Editor of the Copenhagen Discussion Papers:

Associate Professor Michael Jakobsen

\section{Asia Research Centre}

Copenhagen Business School

Porcelænshaven 24

DK-2000 Frederiksberg

Denmark

Tel.: (+45) 38153396

Email:mj.int@cbs.dk

www.cbs.dk/arc 


\title{
Imbalances between the European Union and China
}

\author{
Ari Kokko \\ Asia Research Centre, Copenhagen Business School \\ June 2015
}

\section{$1 \quad$ Introduction}

China's impressive development since the introduction of market-oriented reforms in the late 1970s has had a considerable impact on the world economy. After a first decade and a half of cautious experiments with liberalization, markets, and internationalization, Chinese reforms accelerated in the early 1990s and the Chinese economy started growing at a rate that has not been matched by any other country. The GDP growth rate has averaged nearly 10 percent per year since that time. China has become the world's largest exporter and one of the largest importers, with a huge domestic market driven both by export-oriented industry and nearly 1.4 billion increasingly affluent domestic consumers. It is one of the main destinations for foreign direct investment (FDI) and has also become an important outward investor. The emergence of this new economic superpower has created both opportunities and challenges for other countries. The purpose of this paper is to focus on some of the challenges and to discuss three imbalances that put pressure on the relationship between the EU and China. These concern the large deficit in Europe's trade with China, the unequal conditions for European investment in China and Chinese investment in Europe, and the EU's inability to agree on a common China policy. 
Before turning to these challenges, it appropriate to acknowledge some of the achievements and results of China's economic miracle. China's rapid growth has mainly benefited its own population. Average per capita incomes in the mid-1980s were around USD 300, comparable to those in India. By 2014, China had a GDP per capita of nearly USD 7,000, while the average Indian was struggling to reach a quarter of that. Chinese incomes are not equally distributed across the population, but growth has still lifted hundreds of millions of Chinese out of poverty. As a result, the UN's first millennium development goal-to reduce the share of the global population in extreme poverty by half between 1990 and 2015-was reached already in 2010. China's growth has also benefited other economies. By combining cheap domestic labour with capital and technology from other countries (using the foreign direct investment of multinational enterprises as an instrument), China has built the world's largest manufacturing sector. In many industries, Chinese manufacturing is also the world's most competitive. Foreign companies that have invested in China have reduced their production costs, and many have also managed to improve their profitability, despite the ever tougher competition in the global market. Consumers have benefited from the growing supply of cheap products "made in China", including traditional labour-intensive commodities such as shoes and garments, as well as cell phones, computers, and other high-tech products. The rapid productivity increases seen in the Chinese manufacturing sector have helped keep global consumer prices low. At the same time, producers of raw materials and of industrial commodities have derived benefit from China's expansion in the form of higher export prices. This has been of particular importance for many developing countries, which have managed to reach respectable growth rates thanks to export demand and direct investment from China. As a result, China is not only 
the dominant economy in Asia; it has also become Africa's largest trade partner and foreign investor, as well as an important actor in Latin America.

At the same time, it is obvious that China's growth has put pressure on many other countries. China's share of the world economy has doubled every 8 years since the early 1990s. In 1992, China accounted for 2 percent of world GDP; at the turn of the millennium it had a share of 4 percent; by 2008 it had reached 8 percent; and in 2014 its share is estimated at about 14 percent. If nothing surprising happens, China will reach 16 percent of the global economy in 2016 (at official exchange rates). China's share of world exports has increased correspondingly, to about 13 percent in 2014. Its share of world imports has also grown; however, import growth has fallen short of export growth during the past decade. Large trade surpluses have become a notable characteristic of the Chinese economy since the turn of the millennium.

The result is that many mature industrial economies have lost export shares to China, and been forced to introduce painful structural adjustment processes. Goods that used to be produced at home are now imported from China, while domestic production and exports have been redirected towards industries where China's competitive advantages are weaker. Most of the mature OECD economies have tried to shift towards high-tech industries and knowledgeintensive services.

However, many countries have struggled to find new goods and services to replace their traditional export goods. The trade balance of many of China's trade partners has deteriorated, with large deficits outside China reflecting the large Chinese trade surplus. Large and persistent trade deficits may hinder economic development. Domestic firms may be forced out of business by tough import competition, resulting in a loss of jobs and tax revenue; 
the financial sector may be hit by non-performing loans as the earnings of domestic firms fall; and debts to foreign creditors may grow out of control when a country's export revenues fall short of its import bill. It is not surprising that large trade and current account deficits often lead to financial crisis.

The US, where the global financial crisis started in 2007-2008, has suffered from larger trade imbalances than most other countries. The US debate on the causes of the financial crisis has also been quite intense, often with part of the blame ascribed to China. The trade deficit-and hence part of the responsibility for the financial crisis-has been blamed on an undervalued Chinese currency, which boosts Chinese exports at the same time as it makes foreign goods more expensive in China. China has also been blamed for protecting its market with various non-tariff barriers. There is further criticism against China's high savings and investment rates, which are thought to reduce current consumption and to raise export capacity. Commentators have suggested that China has blocked some of the adjustment mechanisms that would normally contribute to a balancing of the US deficits. One such mechanism operates through a depreciation of the deficit country's currency. A weaker US dollar should result in cheaper US exports and in a corresponding increase in the dollar price of US imports. By fixing the renminbi to the US dollar (until 2005), and then allowing only limited appreciation, China-or so the accusation goes-has blocked this adjustment mechanism. Another adjustment process is linked to interest rate adjustments in the deficit country. A trade deficit is expected to result in higher interest rates, because money is flowing out of the economy to finance imports. These higher interest rates should lead in turn to higher savings and lower consumption and investment, as well as lower imports. Here, China is criticized for its willingness to finance the US current account deficit by investing its own trade surpluses in the American financial 
market. The inflow of Chinese funds arguably contributed to keeping interest rates low before the financial crisis, despite efforts by the Federal Reserve to raise short-term interest rates by absorbing liquidity from the market.

The competition from Chinese exports has been a challenge also for the EU. In 2008, the EU's bilateral trade deficit with China amounted to USD 240 billion, nearly matching the American deficit with China that year (USD 268 billion). Since then, the Union has managed to reduce the bilateral deficit, while the US-China imbalance has grown further. By 2013, the European deficit had fallen below USD 200 billion, while the American deficit had risen to USD 319 billion. But the EU remains vulnerable (both directly and indirectly) to the imbalances caused by Chinese trade surpluses, due to the impact Chinese trade can have on other countries.

The first theme to be discussed in this paper concerns China's export competitiveness, which has contributed strongly to the country's fantastic economic growth, but which has also caused worrisome trade deficits in other parts of the world. In particular, I focus on the reasons for the Chinese export miracle, and on the EU's prospects for managing the imbalances that follow from China's trade surpluses.

The second area has to do with an imbalance that potentially is just as serious as the trade deficit, but which has not received as much attention yet: the asymmetry between the treatment of foreign investors in the European and Chinese markets, respectively. FDI is already a key strategy for European firms trying to reach Chinese consumers, and its importance can be expected to increase in the future. However, many European investors in China meet a market environment where they feel disadvantaged, and where state-owned enterprises (SOEs) are favoured by various rules and regulations. At the same time, Chinese 
firms have begun to expand abroad, and China (including Hong Kong) is now the second largest foreign direct investor in the world, after the US. Chinese FDI in Europe is on the rise, and Chinese investors have almost unlimited access to the EU's single market.

The third imbalance concerns the Union's inability to act as an equal counterpart in negotiations with the Chinese government. Different EU member states have different interests in relation to China. As a result, the EU has no common China policy. This fragmentation has also made it possible for China to maximize its bargaining power, by focusing on bilateral relations with selected member countries. (Such an approach yields greater bargaining power than does entering into a strategic partnership with the EU as a whole.) The main challenge for the EU is to bridge the interests of its member states in such a way as to make it possible for it to act in a consistent and coordinated manner, thus making good results in negotiations with China possible.

This paper is structured as follows: Section 2 focuses on the first imbalance and looks at the reasons for China's export miracle, with some emphasis on the role of the state. It suggests that China's "unnaturally" or "unfairly" strong export competitiveness has already begun to diminish. Section 3 discusses the second imbalance, which relates to the business environment and competitive conditions in the Chinese market, and points to several areas where extensive government intervention distorts competition and discriminates against foreign companies. One conclusion from this discussion is that it will be difficult for the EU to bring about change, particularly in industries that China defines as strategic growth industries. Section 4 looks at imbalances within the EU, and considers the challenges Europe faces in formulating a common China policy. Section 5 summarizes my findings, and suggests that a transatlantic trade and 
investment partnership may offer the best prospects for reconciling the interests of different EU member states and strengthening the Union's negotiating position vis-à-vis China.

\section{International trade: the Chinese export miracle}

Since the early 1980s, China has gradually assumed a more and more prominent position in the world economy. From being an inward-looking and basically self-sufficient economy until the late 1970s, China has proceeded in the last few years to become the world's second largest economy after the US, the largest exporter, and one of the top destinations for foreign direct investment. Exports have been the main driver of Chinese development, and the export share of GDP rose to a peak of almost 40 percent in 2006-2007. Since then GDP growth has been faster than export growth, and the export ratio has fallen to 30 percent. Given the size of the economy, it can still be argued that this is a remarkably high degree of internationalization, inasmuch as large countries tend to have lower export ratios. In India the export to GDP ratio is around 20 percent, in Japan it is 15 percent, and in the US it is about 14 percent. In other words, China has largely based its growth on foreign rather than domestic demand. This export-led development strategy has lifted hundreds of millions of people out of poverty; incomes have risen from 300 dollars per capita in 1980 to 6,800 dollars per capita in 2013. As Figure 8.1 makes clear, growth in incomes and growth in exports have been correlated over time: growth in the former has been faster when growth in the latter has been faster.

Figure 8.1: Exports and per capita incomes in China 1980-2013. 


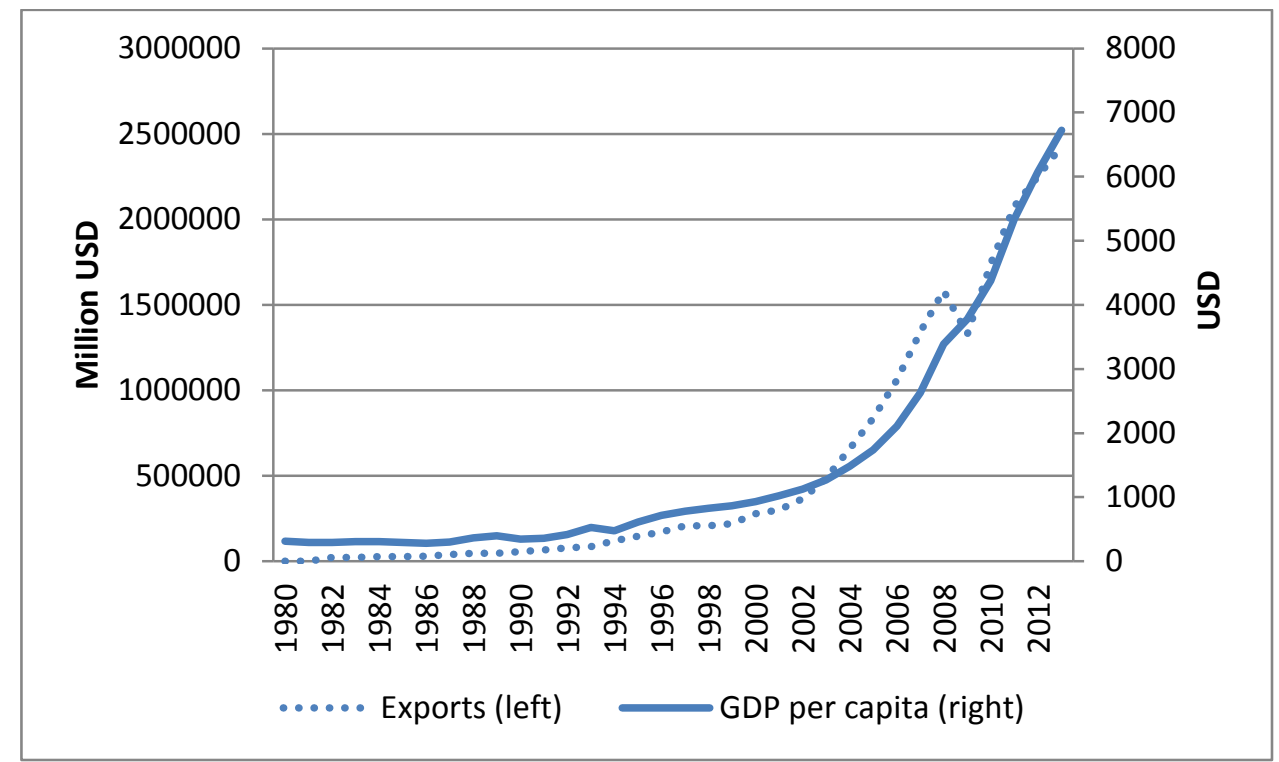

Source: UNCTAD Statistics.

There is no doubt that various policy reforms have contributed greatly to the creation of the Chinese export miracle. The abandonment of the command economy, the de-collectivization of agriculture, and the various other steps taken to liberalize and decentralize the economy are so fundamental that they hardly need to be mentioned. At the same time, there are several other major reforms that have shaped the specific export-oriented model that China represents. The transition from plan to market began in the early 1980s, in the coastal regions of southern China, where a number of cities (and eventually provinces) were allowed to experiment with markets, commerce, and internationalization. The assumption behind these geographically defined experiments was that exports would be the engine of the economythere was simply not enough domestic purchasing power to drive development, since a stagnant command economy remained operative in most of the country for another decade. Another engine of growth was foreign direct investment. China had neither the capital nor the 
commercial technology to conquer the world market. Allowing FDI attracted both of these resources to China. The experiments also led to large differences in regional development. Growth in the coastal regions was much faster than in the rest of the country: a "dual" economy emerged. While coastal towns grew richer and more modern, central and western China remained much poorer and less developed.

The next major steps in the reform process were taken around 1992. Deng Xiaoping, one of the Communist Party's most prominent leaders, made a famous inspection tour of the special economic zones in southern China that year, in order to assess the results of the marketoriented reforms. Deng's conclusions are often summarized with the slogan: “It doesn't matter whether the cat is black or white, as long as it catches mice". (In other words, there is no fundamental contradiction between the market economy and China's particular form of socialism.) In the ensuing debate on the direction to be taken by China's economy in the future, Deng's pragmatic reformist ideas prevailed, as against more cautious conservative and ideological conceptions. The regional experiments were extended to the national level. At the same time, inflows of foreign direct investment began to rise rapidly. A large devaluation in 1994 reinforced the country's export competitiveness and guaranteed the success and survival of the export-led growth model, in an environment where liberalization and decentralization were expected to contribute to significant inflation. With a cheaper renminbi, export prices in foreign currencies remained relatively low despite domestic inflation, and the opportunity to earn increasingly valuable dollars gave individual firms a strong incentive to continue focusing on exports rather than on domestic sales. 
Economic growth in the inner and western parts of China, however, was slow at first. Since the coastal regions had built up a big lead over the previous decade, they were much more attractive as locations for new investment. They had better infrastructure and a larger supply of skilled labour, and their local authorities had learned to operate in a market economy. As Figure 8.2 shows, the coastal provinces remained remarkably dominant in 2006, accounting for a disproportionate share of exports, investment, and GDP.

The subsequent stage in the country's economic transformation came in the early 2010s, in the form of WTO membership. The clear message conveyed through China's accession to the WTO was that Chinese exporters would now have a more predictable export environment: in most cases, they could expect relatively free access to the major export markets. There had been some uncertainty earlier about access to foreign markets, because the multilateral rules on market access and equal treatment only apply to trade among WTO members. As we saw in Figure 8.1, China's export growth accelerated at this time, and its trade and current account surpluses started to rise quickly. (Before the turn of the millennium, by contrast, China had rarely recorded large trade or current account surpluses.)

Figure 8.2: Distribution of GDP, FDI, exports, and population across regions, 2006. 


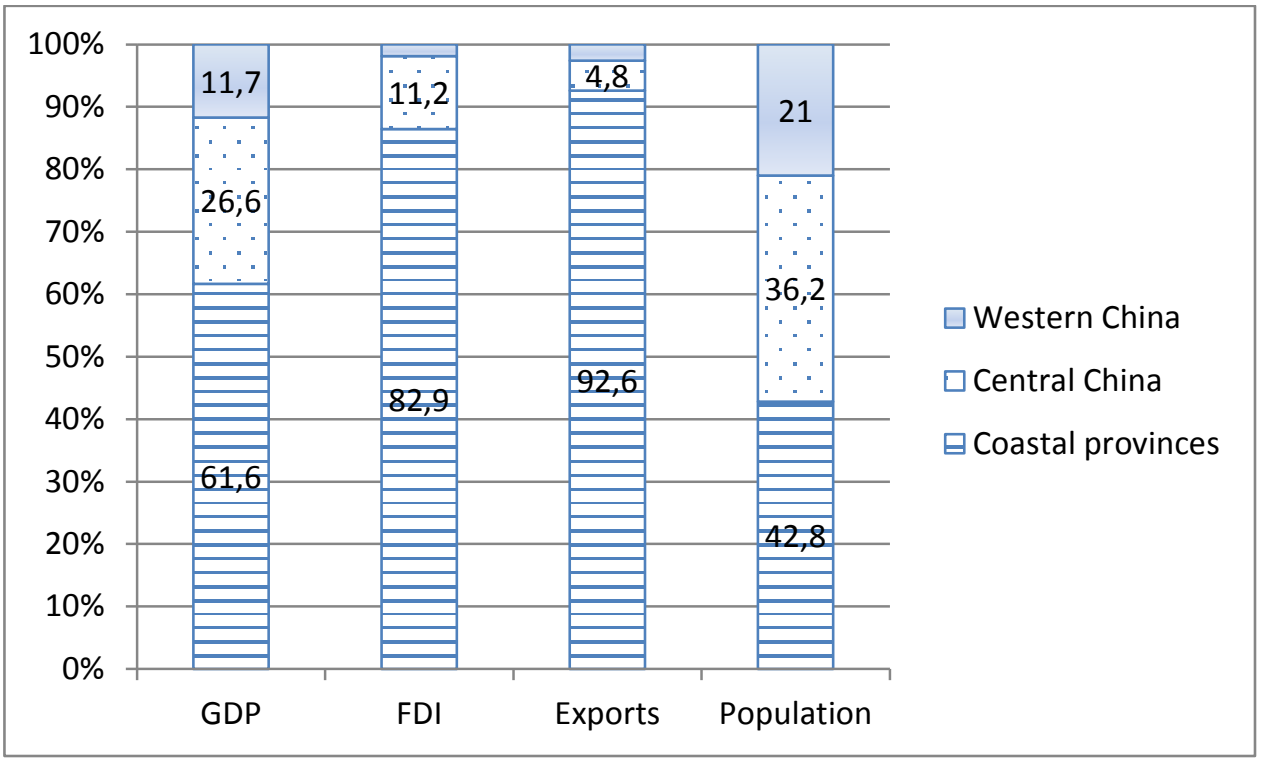

Source: National Bureau of Statistics.

\subsection{Demography and geography}

Market reform, liberalization, foreign direct investment, currency devaluations, and WTO membership are some of the building blocks of the Chinese export miracle. In addition, there are geographic and demographic reasons for China's competitiveness. These are to some extent related to the specific export-led development strategy chosen by the Chinese leadership. I noted above that this policy resulted in large geographic fissures in the country's development, with a dual economy and a large lead for coastal areas. While the coast was industrialized and urbanized, the hinterland remained largely agricultural. This duality contributed greatly to the ability of coastal export-oriented industries to maintain their international competitiveness over time. Although both total employment and labour productivity in manufacturing have increased significantly, wages in labour-intensive export industries remained relatively low for many years. A large pool of cheap labour was available, 
in the form of low-paid and often underemployed people from central and western China, who were willing to take manual jobs in the coastal provinces. Even low wages were enough to entice them to move from their home province, because the alternative-staying at home and subsisting on yet lower incomes from small-scale farming-was even less attractive. Estimates on the number of domestic migrants or "floating workers" vary, but even conservative estimates suggest that at least 190 million people were working outside their home province in 2005. The absence of independent trade unions has also helped to keep wage levels low. The existing unions are controlled by the Communist Party, and unsurprisingly they have chosen not to threaten China's export competitiveness by demanding wage increases that match or exceed increases in labour productivity.

The one-child policy has given further impetus to the export strategy. This policy is important because it has contributed to a low dependency ratio: that is, a low percentage of the population that is not of working age. As Figure 8.3 shows, only just over a third of the Chinese population is too young or too old to participate in the workforce. This is one of the lowest figures among the 214 countries covered by the World Bank statistics database: only the UAE and Qatar record clearly lower dependency ratios, while Singapore and Hong Kong are at around the same level as China. A demographic structure of this type gives poor countries an excellent opportunity to generate economic growth and development. A low dependency ratio means that only a small part of aggregate income need be set aside to support children and the elderly. This leaves a lot of room for saving and investment, thereby raising the economy's productive capacity. Moreover, a large part of this capacity gets focused almost automatically on exports, because a high savings rate, by definition, means that domestic consumer demand is low. 
Figure 8.3: Dependency ratio, China 1960-2013. Elderly (above 64 years) and children (below 15 years) as a share of the working age population (15-64 years) (\%)

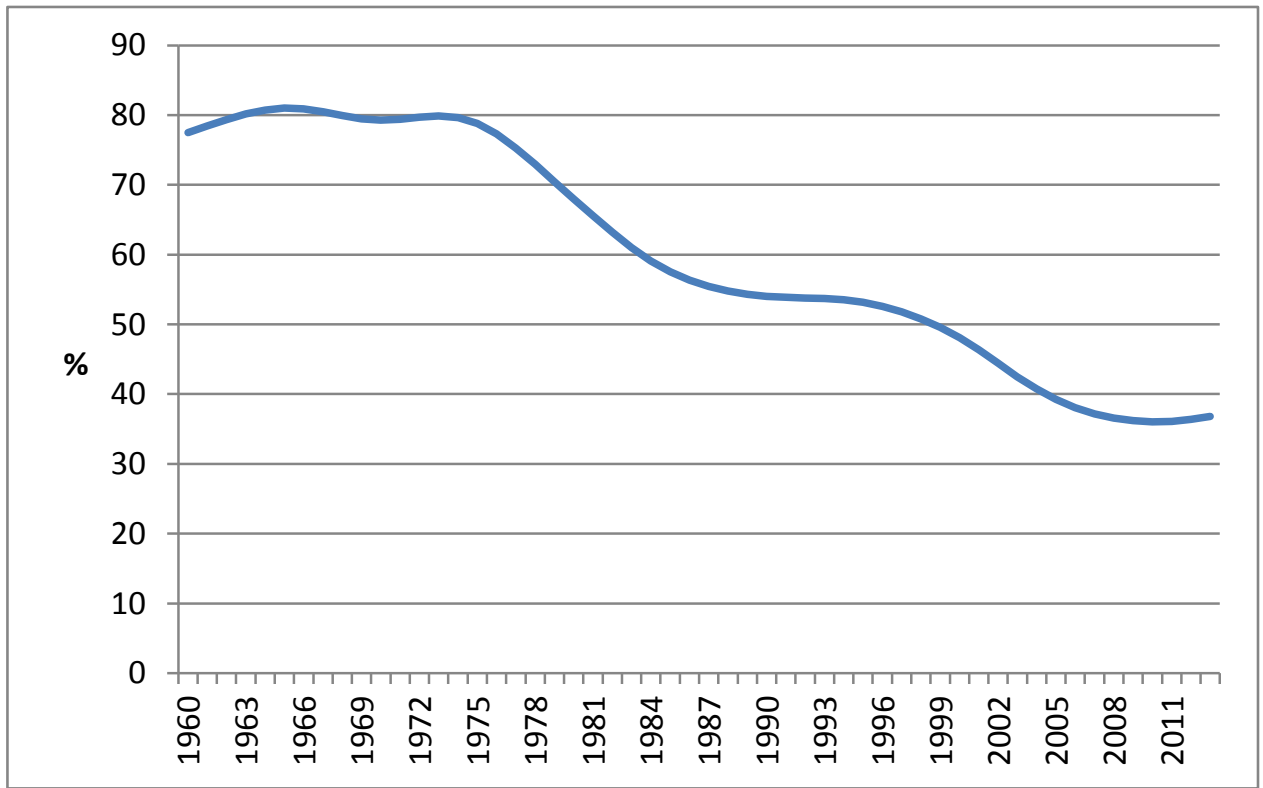

Source: World Bank Databank.

At the same time, it bears noting that a high savings rate is not always the obvious choice for a poor household. Poor households often feel that the benefits of higher consumption are quite considerable at the margin; thus it is not easy to persuade them to save a high share of their income. In China, however, most households have strong incentives to save. The lack of public investment in social welfare has forced them to save, for both predictable and unpredictable expenses. Although primary education is nominally free, it is common that children feel obliged to attend extra classes after the regular school day. Low wages have forced teachers to save important parts of the course curriculum for these extra classes, where "voluntary" 
tuition fees are expected. Health care has been commercialized, and few procedures are completed without extra payments to doctors and nurses. The poorly developed pension system forces people to save for their old age. In addition, the one-child policy means that elderly persons cannot rely much on support from their children. In recent years, finally, rising housing prices and stiff requirements for down-payment have added a strong motivation for high household saving.

Yet, the passion of Chinese households for saving does not explain more than perhaps half of China's total savings. One thing that distinguishes China from most other countries is that the corporate sector and the government in that country also exhibit a very high propensity to save. China's remarkably low wage levels are a major reason for this. Due to the combination of a large underemployed labour pool with a lack of independent trade unions, capital owners have been able to capture a large share of the labour productivity gains generated in industry. Wages simply have not grown as fast as labour productivity has. Despite fierce competition in the Chinese market, the capital share of China's value added (and GDP) increased steadily for over 20 years, from the late 1980 s to about 2010 . By the latter date the capital share had risen to two-thirds, at the same time as the wage share had fallen to one-third. By way of comparison, many mature market economies have recorded wage shares of around 65 percent of GDP during the past decade. Although some of the capital share of value added is ultimately used for consumption (since some households own productive capital), the larger part of returns on capital has been used for new investment. State enterprises have rarely had to pay profit shares to their owner; instead they have been allowed to reinvest their profits. Small and medium-sized private enterprises have also been forced to finance much of their growth from reinvested earnings, since Chinese banks have preferred to lend to SOEs and to 
large private corporations with good political connections. These reinvested earnings represent corporate savings (and thus are recorded as both saving and investment in the national accounts). Where public finances are concerned, it bears noting that the low level of public spending on social welfare means that a large percentage of the state budget is available for investment, mainly in infrastructure. This high level of tax-financed public investment also registers in the national accounts as a high public savings rate.

Yao Yang, a leading economist at Peking University, has accordingly described the Chinese growth model as a virtuous cycle, wherein successful export constantly creates new competitiveness. The initial export success leads to profits, which are reinvested in new machinery and technology that make the workforce more productive. Then, since wages do not rise as rapidly as productivity does (and since the renminbi has not been allowed to appreciate significantly), the result is rising competitiveness, exports, and profits. This in turn yields resources for new investment, which leads to further labour productivity gains, and so on. As a result, Chinese industry is favoured both by low labour costs (due to the large supply of cheap labour with little bargaining power) and low capital costs (because there are plenty of reinvested profits that are cheaper than borrowed capital). The main imbalance in the Chinese economic system, from an international perspective, is therefore not the undervalued currency, but rather the artificially low wage share of GDP. Given the rapid economic progress seen in China, workers in that country have been grossly underpaid during the last decade.

\section{$2.2 \quad$ The road to balanced trade relations}

A more flexible Chinese exchange rate (read: a more expensive RMB) would probably help reduce China's export surplus, but long-term solutions to global trade imbalances cannot be 
sought in the area of exchange rate policy. Instead, balancing requires that China allow the wage share of GDP to rise; thereby boosting domestic consumer demand and reducing exports. Without an increase in domestic consumption in China, it is possible that an appreciation of the currency will be offset by a continued gap between rapidly increasing labour productivity and slower wage growth. The experience of Japan's endaka period, which began in the mid-1980s, is a cautionary tale that contributes to China's reluctance to use its currency as a balancing instrument. Japan's current account surplus grew rapidly during the first half of the 1980s, with a corresponding increase in the US deficit. Intense international pressure led to the so-called Plaza Agreement of 1986, whereupon Japan allowed the yen to appreciate. In one year, the value of the yen increased from 240 yen per dollar to 130 . Yet, the US deficit did not disappear. One reason for this was that Japanese exporters managed to raise domestic labour productivity, so that their export competitiveness was maintained. Moreover, Japanese firms began to outsource labour-intensive production to China and Southeast Asia. Yet, the deficit in the US domestic savings-investment balance was not reduced: private consumption and investment remained high. This underlines the need for adaptation in European and American domestic accounts today as well. Higher public and private saving in the West is needed to bring down our deficits.

What can or should the EU do to nudge China towards an equilibrium with a higher wage share, higher domestic consumption and imports, and a reduced emphasis on export-led growth? The answer is probably that the EU does not need to do anything at all-the adjustment process is already underway. Chinese leaders have been forced in recent years to rethink the export-driven growth model for several reasons. Global trade imbalances are one reason. China already has a large surplus in most of its trade relations with OECD countries, 
and it will not be easy for the EU or the US to absorb even more Chinese goods and servicesat least not at the same rate as during the past decade. There is still scope for increasing exports to emerging markets and developing countries, but these export markets are significantly smaller than those in the rich OECD nations (although their growth rates are often considerably higher). Exports will simply not be able to deliver long-term growth rates at the levels China is aiming at.

A further reason for reassessing the country's growth strategy is that the distorted distribution of value added has created inequalities and social imbalances. China's Gini coefficient, which measures the degree of inequality in income distribution, has reached nearly 0.50 in recent years. This is higher than the level in most of Africa, and comparable to that in countries like Mexico and Argentina. The nations of the Nordic region, which are among the world's most equal, have Gini coefficients of about 0.25 . The growing inequality in China reflects not just the fact that a large share of productivity gains accrue to owners of capital; it also registers the widening gulf between urban and rural areas. Likewise, the gap between high-skilled and lowskilled workers has grown greater over time. There is justified concern that large income differences can lead to corruption and crime, as well as to a deeper dissatisfaction with society that may eventually become a threat to the country's political stability. For example, labour relations in many industries and provinces are tense, and strikes and labour disputes of various kinds are common. ${ }^{1}$ There are significant pressures for higher wages and better working

\footnotetext{
${ }^{1}$ A political threat that often appears in connection with labour disputes concerns the position of trade unions. The official trade unions are tightly controlled by the party and are rarely involved actively in disputes, except when such disputes concern foreign companies or when they underscore official Chinese policy (e.g., strikes at Japanese subsidiaries in periods when China and Japan are at odds over territorial or other matters). When unexpected and
} 
conditions. The rapid public response to a widely reported wave of suicides at Foxconn's Shenzen factory in southern China in 2010 (which was probably caused in part by low wages and poor working conditions) shows that these concerns are taken seriously by the Chinese authorities. Shortly after these events, minimum wages for Foxconn workers were raised by 30 percent. Regional authorities in Shenzhen and other parts of China soon followed suit with similar wage increases. On average, minimum wages have risen by more than 20 percent per year since 2010 , halting a 20 -year decline in the wage-to-GDP ratio.

The 12th Five-Year Plan, which covers the 2011-2016 period, highlights several of the reforms that are necessary to change the character of the Chinese economy. Domestic demand will be increased, and consumption rather than investment will drive the economy. For this to happen, the wage share of GDP will have to be raised. However, while the plan states an ambition to raise minimum wages, it says nothing about how an increase in the wage share is to be achieved. This may be because market forces have already triggered the necessary adjustment process.

Two ongoing processes are currently influencing labour supply and wages in Chinese industry. The first one concerns the excess supply of labour in the countryside, which has provided the pool of migrant labour that has kept manufacturing wages relatively low. Analyses of the rural sector show there is not much surplus labour left, and that the marginal productivity of labour is rising (Cai 2010 ; Zhu and Cai 2012). This suggests China has reached the stage of

unplanned strikes and labour disputes occur, there is always a risk that workers will spontaneously choose their own representatives - an obvious threat to the Communist Party's dominance and monopoly on political power that cannot be tolerated. When such events occur, therefore, the problem is often resolved quickly, either through intervention by the police or military or through assent to the workers' demands by the employer. 
development called the "Lewis turning point", where marginal incomes in agriculture and manufacturing have been more or less equalized, and the manufacturing sector can only attract additional workers by offering higher and higher wages. The more people that leave agriculture after this turning point, the higher the reservation wage for those who remain. With fewer workers in farming, moreover, there is an increase in the amount of agricultural land per remaining worker, which results in higher labour productivity and incomes.

The second process relates to demographics and the one-child policy. In recent decades, the declining dependency ratio reflected a reality where the great majority of the population belonged to the labour force and competed for jobs. Now, however, the one-child policy is beginning to affect the dependency ratio in the opposite direction. The largest age cohorts are made up of people born before the restrictions on the number of children were introduced in the early 1970s; today, these cohorts are already over 40 years old. The median age in China today is about $36-$ not far from the 37 in the US and Northern Europe's 40, but a long way from the 25 found in many developing countries. According to the United Nations Population Fund, the median age in China will increase to around 42 before 2030, which will be similar to the figure in Northern Europe and well above the 40 projected for the US. It is also likely that 50- and 60-year-olds in China will not be as productive as their counterparts in Europe and the US. Far from all of them will be able, after a life of hard work in an unhealthy working environment, to keep working until they reach the formal retirement age (60 for men and between 50 and 55 for women). Moreover, since population growth rates in recent decades have been low, few young people are entering the labour force. More and more young people today are also able to get a tertiary education, delaying their entry into the labour market. The number of workers available to China's manufacturing machine is no longer increasing; 
instead, labour is becoming a scarce resource. The rapid wage growth registered in recent years reflects this reality. As a result, China's edge in export competitiveness will be reduced.

Under the title "The End of Cheap China", Rein (2012) describes some of the changes that are necessary due to rising wage costs. Some labour-intensive firms are moving from China to countries such as Vietnam, Indonesia, and Bangladesh, where wage costs are a fraction of those in China. Other companies survive by relocating to the country's interior, where costs are still lower than in the developed coastal regions. Many companies also handle the cost increases by raising labour productivity: higher educational levels, modern infrastructure, and relatively low costs for mechanization and automation give great scope for increased efficiency. Most of the foreign companies being squeezed by higher labour costs are shifting some of their production in China from exports to domestic sales. This entails new challenges. As long as their intended market was outside China, foreign companies could often avoid problems connected with local competition. With a stronger focus on the domestic market, such issues become more important.

\section{3}

\section{Direct investment and multinational enterprises:}

\section{the changing role of China}

Foreign direct investment played an important role already in the early 1980s, during the first Chinese reform experiments. Foreign entrepreneurs furnished many resources which were lacking in China's command economy: financial capital, technology, and knowledge of foreign markets. In addition to the jobs and tax revenues created by these foreign investors, important benefits for the Chinese economy were thought to result from knowledge flows between 
foreign and domestic companies (the latter included joint venture partners, suppliers, and customers of foreign multinationals). Some of the knowledge possessed by foreign firms would "spill over" to domestic companies and contribute to their growth and internationalization. The foreign firms were generally not seen as direct competitors to local businesses, but rather as a complement to them. Direct investment was focused on exports, and the world market was believed to be big enough to absorb the exports of both multinationals and local companies. The domestic market was less attractive to foreign investors, because incomes and purchasing power were still low. The Chinese government encouraged inflows of FDI with tax benefits, public investment in infrastructure, and the allocation of land and factory buildings.

Inflows of FDI were still relatively small in the 1980s, because China was an unknown and uncertain market. Growth took off, however, when market-oriented reforms were confirmed following Deng Xiaoping's coastal inspection tour in 1992. Then, as Figure 8.4 below shows, there was another phase of strong FDI growth in connection with China's WTO entry in 2001. This expansion has made China (together with Hong Kong) the world's largest recipient of FDI in recent years. EU companies have accounted for about one-fifth of capital inflows to China. China provides offshoring opportunities, but the latest wave of investment is also driven by the growing market within the country. As Chinese wages rise and the RMB slowly becomes stronger, a heavier focus on the local market becomes rational even for investors that originally saw export as their primary goal.

Figure 8.4: Annual FDI inflows to China, Hong Kong, and the USA 1980-2013 (million USD) 


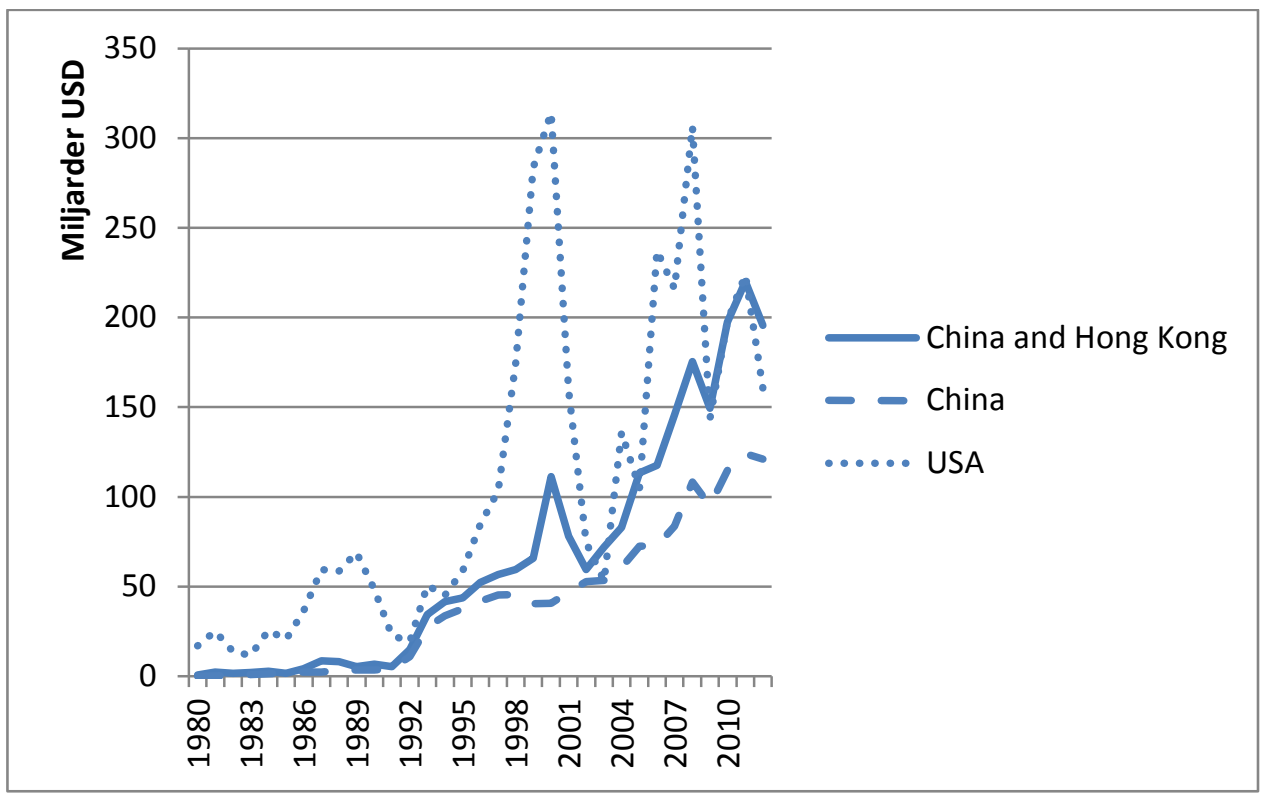

Source: UNCTAD Statistics.

For a long time, there was a large imbalance between growing inflows of FDI to China and very limited outflows of investment from that country. This imbalance was not surprising, given China's low levels of income and development. To become multinational, companies do not just require capital; they also need some proprietary assets, which enable them to survive in foreign markets where established local firms have an advantage, due to their superior knowledge of local market conditions. Developing proprietary assets (e.g., brands and technical innovations) takes time. John Dunning's well-known Investment Development Path model shows how countries can be expected to have large net inflows of FDI when incomes and labour costs are relatively low, and how outflows of FDI tend to increase as incomes and development levels rise. In the typical pattern suggested by Dunning, it is not until a country reaches middle-income status - with a per capita income of 10-15,000 US dollars per yearthat investment outflows begin to increase significantly (Dunning et al 2008). 
The Chinese pattern, however, has been different. Figure 8.5 shows that FDI outflows from China began to grow rapidly around 2003-outflows of FDI from Hong Kong had started ten years earlier-and that China and Hong Kong together already had a relatively balanced investment position at that time. ${ }^{2}$ In 2013, they jointly registered FDI inflows of just over 200 billion US dollars, while their outflows came to over 190 billion US dollars. China has thus become an important foreign investor over the course of the last decade. What is remarkable is that this internationalization began at a much lower income level than in other countries. In 2003, average per capita income in China had not yet reached 2,000 US dollars, and it is still (in 2014) below 7,500 US dollars.

One reason for China's deviation from the "normal" investment development path is to be found in its pronounced regional differences. The country's low average income level does not reflect the prosperity achieved in the most advanced parts of the country. In Beijing and in coastal cities like Guangzhou, Shenzhen, Wenzhou, Hangzhou, Suzhou, and Shanghai, per capita incomes are more than twice as high as the national average (as well as clearly higher than per capita incomes in the countries which have joined the EU since 2004). Another and possibly yet more important reason for China's deviation is that its government has defined internationalization as an important strategic goal for the country's development. The state has therefore provided various kinds of support to help the largest companies gain access to

\footnotetext{
${ }^{2}$ It should be noted there is a debate about so-called "round-tripping", whereby Chinese firms move capital to Hong Kong and then re-invest it in China, in order to get some of the various benefits designed to attract FDI to the economy. The same problem applies to some extent to Chinese investment in the Virgin Islands, the Cayman Islands, and other tax havens. There is not enough information to assess how serious the resulting distortion in the data is, but it is clear that round-tripping leads official statistics to overstate FDI outflows. At the same time, it is likely there are other investment outflows which are underreported. Aggregate statistics on China's FDI outflows should thus be treated with some caution.
} 
foreign markets. The most important measures are related to financing, but the Chinese authorities have also given valuable political support to companies, as well as investment guarantees. This has been particularly important in developing countries, where China's overseas investment is integrated with aid and diplomatic relations.

Figure 8.5: Annual outflows of FDI from China, Hong Kong, and the USA 19802013 (million USD)

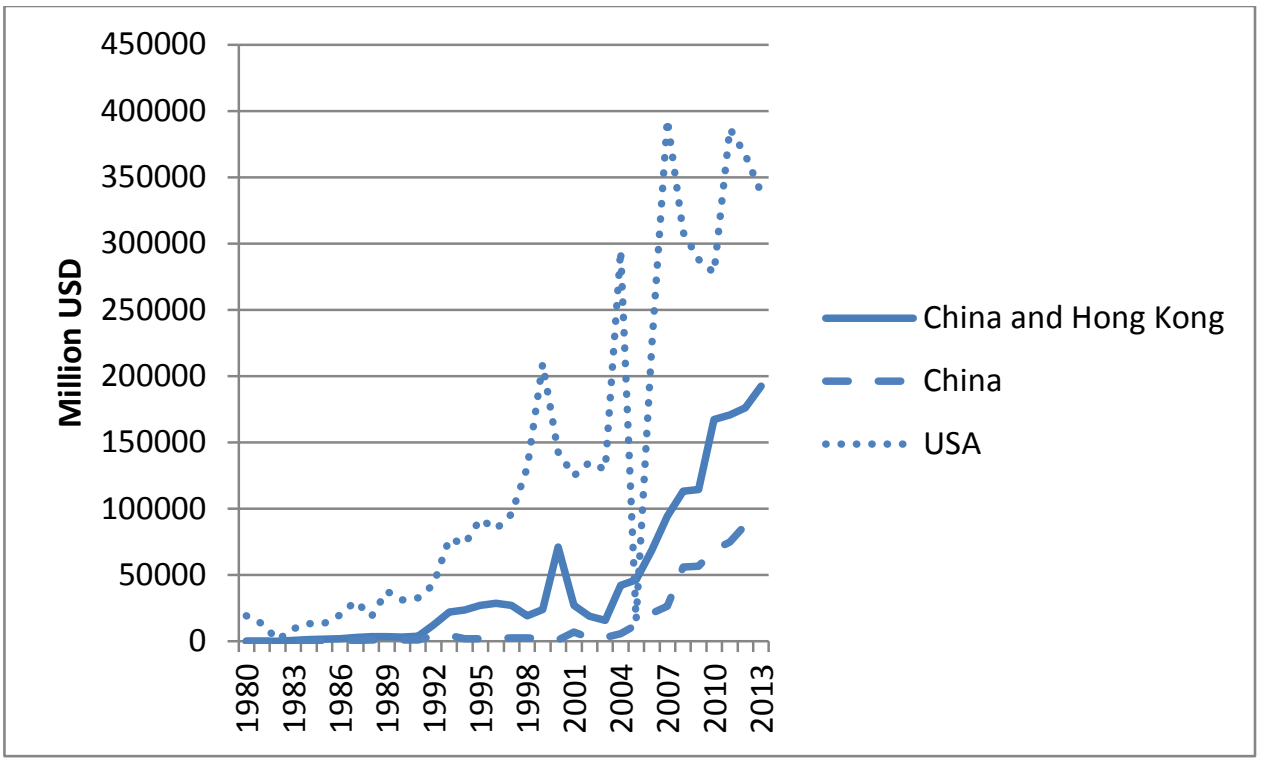

Source: UNCTAD Statistics.

Initially, the aim of this strategy-known under the slogan "Go Global" - was to secure raw materials for the Chinese economy. As a result, most of China's outward FDI has gone to projects in oil and gas, mining, forestry, agriculture, and other commodities in developing countries of Asia, Latin America, and Africa. Data for 2007 show that only 3.8 percent of the total value of Chinese FDI went to Europe, and Chinese investment accounted for less than one 
percent of the aggregate inflow of FDI to the EU. North America accounted for just 2.8 percent of the total.

Chinese investment in Europe has increased since then, as other motives than access to raw materials have become more important: in 2011 and 2012, Europe's share of China's outward FDI rose to nearly 10 percent. The US share of China's overseas investment was about 5 percent. ${ }^{3}$ Table 8.1 shows the top ten European recipients of Chinese FDI since the turn of the millennium.

Table 8.1: Chinese FDI in the EU 2000-2011, ten main destinations (million USD and number of projects)

\begin{tabular}{|l|l|l|l|}
\hline & $\begin{array}{l}\text { Cumulative value } \\
\text { (million USD) }\end{array}$ & $\begin{array}{l}\text { Total number } \\
\text { of projects }\end{array}$ & acquisitions \\
\hline France & 5722 & 70 & 24 \\
\hline UK & 3684 & 95 & 26 \\
\hline Germany & 2543 & 146 & 33 \\
\hline Sweden & 2251 & 20 & 6 \\
\hline
\end{tabular}

${ }^{3}$ It is difficult to get accurate information on China's overseas investment; statistics from different sources often vary widely. In particular, it is hard to identify final destinations for China's outward FDI. For example, Nicolas (2009) notes that, according to official statistics, nearly 80 percent of China's foreign direct investment in 2007 went to Hong Kong, the British Virgin Islands, and the Cayman Islands. Only rarely, of course, are such tax havens the final destination for these capital flows; but existing statistics do not reveal where the investment ends up. 


\begin{tabular}{|l|l|l|l|}
\hline Hungary & 2065 & 18 & 4 \\
\hline Netherlands & 1164 & 47 & 15 \\
\hline Belgium & 847 & 15 & 3 \\
\hline Greece & 714 & 5 & 0 \\
\hline Italy & 554 & 47 & 16 \\
\hline Austria & 391 & 11 & 5 \\
\hline
\end{tabular}

Source: Ernst \& Young (2012)

Some of the new motives for outward FDI are macroeconomic. The global financial crisis that started in 2008 demonstrated the riskiness of China's strategy of primarily investing its current account surpluses in US Treasury bonds. Furthermore, investing in real assets in developed countries both is relatively safe and offers greater returns than does investing in government bonds. Hence, an increasing share of the current account surplus is used to fund FDI. There are also at least three additional new motives for internationalizing Chinese industry: (1) outward FDI, it is believed, will contribute to China's development by creating markets for Chinese products; (2) it will help Chinese companies access foreign research and technology; and (3) it will enhance the competitiveness of Chinese companies in the home market. Acquiring Western companies with established market shares, brand names, and R\&D resources can be a convenient way to meet all three objectives. Geely's purchase of Volvo Cars is a good example of this, as is Lenovo's purchase of IBM's personal computers branch. Other Chinese companies too have succeeded, in growing numbers, in establishing their own brands, and they are now aiming to conquer market shares in Europe, North America, and Japan. Examples of such 
Chinese brands are Haier (white goods), Huawei (telecom), and ZTE (cell phones). It is not difficult to foresee that, in years to come, the West will make the acquaintance of many other Chinese brands also.

The need to strengthen the competitiveness of domestic firms in the home market is related, both directly and indirectly, to China's accession to the WTO. WTO membership resulted not only in the impressive export boom that started around the turn of the millennium; it also opened the Chinese market to foreign competition. An important part of this increase in foreign competition comes about as a consequence of international trade: as a WTO member, China has committed itself to reducing tariff barriers and to applying fair and transparent trade regulations. However, the boom in inward FDI that followed China's WTO accession has probably been even more important. The world's leading companies are not only trying to export to China from their home countries; they are also present in the Chinese market through their FDI ventures. When these foreign investors redirect an increasing share of their production from exports to domestic sales, Chinese companies will struggle to maintain their market position. The Chinese government has obviously taken note of this challenge. While export-oriented foreign companies that came to China before the global financial crisis were welcomed, it is already clear that existing foreign investors that are currently shifting their focus towards the domestic market will not always be treated equally well. The same goes for new investors heading to China to compete with local companies.

This has led to the next great imbalance in relations between the EU and China. While the investment imbalance a decade ago mainly had to do with the volume of investment-a lot from the EU to China, almost nothing the other way-the new imbalance has much more to do 
with investment conditions and competition. The European market is relatively deregulated, and Chinese investors can usually expect the same treatment as local companies. In the Chinese market, however, the converse does not apply. Foreign investors face extensive regulation and cannot expect equal treatment. Discrimination against foreign firms occurs not only in the case of so-called "infant industries", where local companies are so small and underdeveloped that they cannot be expected to cope with competition from foreign multinationals. It is also found in the case of strategic industries, where Chinese companies have already become multinational and have invested in Europe and other developed markets.

Figure 8.6 shows the OECD's index of investment restrictions in China, the EU, and some other selected economies in 2013. The index gives a weighted measure of different types of investment rules and restrictions: limits on foreign ownership, licensing mechanisms, rules for foreign staff, and various other limitations and requirements in 22 sectors per country for the OECD and the G20. The index value ranges from 1 (completely closed to foreign investors) to 0 (fully open). With a value of 0.42 , China has the most regulated and restrictive policy environment of all 58 countries included in the index.

Figure 8.6: OECD regulatory restrictiveness index 2013, selected countries 


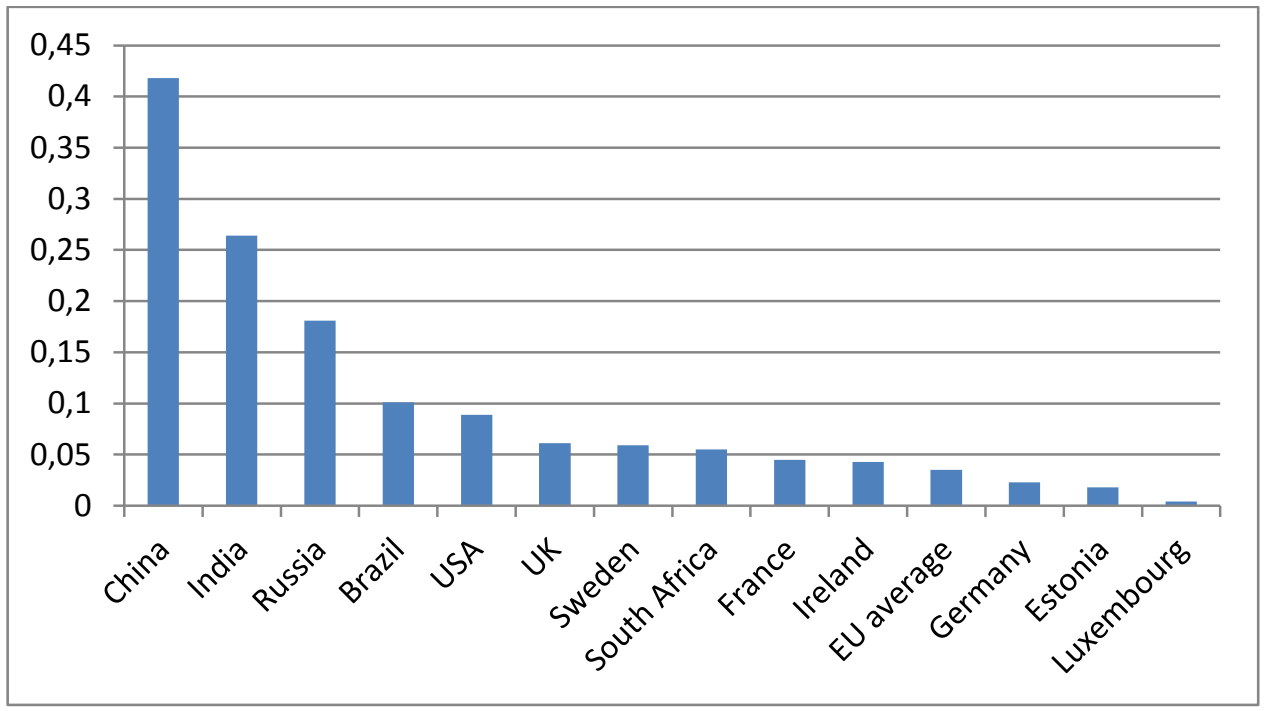

Source:OECD Regulatory Restrictiveness Index, http://www.oecd.org/investment/fdiindex.htm

Among emerging markets, India and Russia also apply extensive restrictions, while Brazil and South Africa have a somewhat more liberal environment. Among the rich countries, New Zealand, Canada, and Iceland exhibit the most restrictive FDI environments. Generally speaking, the EU countries are among the most open, with an average index value below 0.04 . The only non-European countries with figures comparable to or lower than the EU average are Argentina and Colombia.

\subsection{Chinese investment in Europe}

The European Chamber of Commerce in China has recently examined the conditions for Chinese direct investment in Europe. Its analysis confirms the image of the EU as a region with relatively few administrative barriers to incoming FDI (European Chamber 2013a). One of the few obstacles reported by Chinese investors concerns EU competition law, which requires all major mergers and acquisitions to be investigated by the relevant competition authorities. This 
requirement also applies, however, to transactions of this kind among European companies. Overall, Chinese investors rate the European investment environment as more liberal than that in the US or Australia, where arguments relating to national security have been used more frequently to block Chinese projects.

However, the relatively low formal entry barriers for FDI should not be interpreted as a guarantee for a painless investment process. A large proportion of Chinese investors report difficulties and obstacles in connection with regular everyday operations. In particular, there are complaints about cumbersome labour regulations, tax and accounting rules, and rules for visas and work permits. Except where visas and work permits are concerned, these challenges are not unique to Chinese investors: they apply as well to new local businesses and to EU firms investing outside their home country. Investing in market-specific knowledge is necessary in order to adapt to any new business environment. Furthermore, it is reasonable to expect such regulatory obstacles to decline in importance over time, as Chinese investors learn to operate in the EU market. Many Chinese investors also report problems arising from negative perceptions, among European consumers, of Chinese companies and Chinese product quality. These problems too are likely to diminish over time, as European consumers grow more accustomed to Chinese brand names.

It should be noted in this connection that one reason for the negative perceptions in Europe (and the US) is that a large part of Chinese investments is made by SOEs. SOEs account for over 70 percent of Chinese investment value in Europe, and the Chinese state is also involved in much private Chinese investment. In most developing countries, where the bulk of Chinese FDI is in energy and raw materials, SOEs are even more dominant. Foreign investors face some 
degree of scepticism in most economies, and the distrust is even greater in the case of foreign investors which are state-owned, because it is not always clear what the foreign state aims to achieve over the long term. Private owners tend to behave in a predictable manner, with profit maximization as their chief objective; but a state may have other strategic motives that make it hard to predict its decisions and priorities. Nor is it just the Chinese state that faces suspicions of this kind. Volvo's failed merger with Renault in 1993 illustrates the general character of the problem. One of the decisive Swedish arguments against the merger plan was the fact that Renault was a state-owned French company, which could be expected for the most part to favour French rather than Swedish interests. The acquisition of Volvo six years later by Ford, a private company, did not provoke as fierce a debate. However, the acquisition of Volvo in 2010 by the Chinese company Geely led to a renewed discussion about ownership and national priorities. Among other things, the case illustrated the difficulty of categorizing the ownership characteristics of large Chinese corporations today. Geely is formally a private company, but its acquisition of Volvo was supported by the central Chinese government, and local authorities in Shanghai and Daqing are listed as major shareholders of Geely. The distrust of China's government as a foreign investor is not likely to disappear for the foreseeable future-not as long, at any rate, as it chooses to manage the Chinese economy with instruments and objectives that are unfamiliar to observers in Western market economies.

\subsection{European investment in China}

There is a clear contrast between the regulatory environment for Chinese companies in the EU and that for EU companies in China. Alongside its analysis of Chinese investment in the EU, the European Chamber of Commerce in China carried out a detailed study of the conditions for EU 
investment in China. The study describes an environment where government intervention and state ownership of productive resources systematically distort competition and discriminate against foreign investors, particularly in industries and sectors which the Chinese government sees as having a strategic value (European Chamber 2013b). Since the onset of the global financial crisis in 2008, regulations have gotten tighter in several areas. Moreover, the large Chinese stimulus package launched in response to the crisis was primarily aimed at SOEs, and it reinforced their dominant position in the market.

Market access is one of the main problems for foreign investors in China. The Chinese authorities restrict FDI in several sectors and require joint ventures with Chinese investors in many others (often limiting foreign owners to a minority stake). The conditions for new foreign investment projects are listed in a regularly published and highly detailed catalogue-the Foreign Investment Catalogue-which covers hundreds of industries and products. For example, the Catalogue for 2012 prohibited FDI in postal services, energy, media, the defence industry, and parts of the mining industry. In the automotive industry, foreign owners were not allowed to own more than 50 percent of a joint venture, and foreign ownership limits in the financial sector were even stricter. The total foreign ownership share in a Chinese bank could not exceed 25 percent, with a maximum of 20 percent for any individual foreign investor. FDI was also restricted in such industries as hotels, real estate, chemicals, pharmaceuticals, telecommunications, construction equipment, certain food products, and transportation and communication. In addition, licensing requirements were imposed on travel agencies, construction companies, and suppliers of oil products. Often the rules for licensing are designed in such a way as to benefit local SOEs. Indeed in some industries, like oil, it is incumbent SOEs that administer licenses and quotas for new entrants. 
Foreign investors that have already entered the market face a difficult environment too. In particular, they perceive the rules for government procurement as a major problem. The total value of new Chinese government procurement contracts comes to nearly 20 percent of GDP. Foreign companies, however, are rarely involved in this area, other than as partners of or subcontractors to the SOEs that are awarded most contracts. For example, the framework for the procurement of cars by government agencies identifies 412 vehicle models that are allowed as company cars. All of these models are produced by domestic companies; not even the foreign brands and models which are made in China qualify for the list. In conjunction with its accession to the WTO, China undertook to sign the international Agreement on Government Procurement, which establishes basic requirements for transparency and competition. 13 years later, however, China has yet to sign the Agreement.

Another area where foreign companies face notable problems is in innovation and R\&D. In China, the state has a leading role both in identifying and funding new products and technologies, and in creating markets for innovations. The government lists priority areas for innovation in detailed catalogues, which set out the industries and products it wishes to promote. These catalogues affect the allocation of resources for R\&D and investment, at both central and local (provincial) levels. The latest catalogue (Guiding Catalogue of Key Products and Services in Strategic Emerging Industries, published in March 2013) lists more than 3,000 products and services in seven strategic sectors where China hopes to become a world leader. To some extent, especially when domestic enterprises lack the necessary technologies and skills, these are also the sectors where China welcomes new FDI. 
Table 8.2 below identifies the seven strategic emerging industries. To stimulate the development of local capacity, the government provides resources in the form of R\&D funding and investment and production subsidies. The government also gives subsidies to consumers, and uses public procurement as an instrument to create markets for new products. Foreign companies are rarely included in such government-supported innovation processes.

Kokko and Liu (2011) describe the state-led innovation system for the electric car sector, which the Chinese government has classified as one of the core strategic industries. To be eligible for government subsidies and R\&D funding, the cars must be produced in China under a Chinese brand. For a brand to be registered, the applicant must share its key technology with the Chinese authorities, which obviously limits the incentives for non-Chinese companies to participate in the programme. Foreign companies taking part in publicly funded R\&D programmes in China are also constrained by rules that confer the formal ownership of research results on the Chinese partner or financier. Further challenges for foreign companies arise from Chinese product regulations and product standards. These commonly differ from international standards, being based instead on solutions developed by leading local (stateowned) companies. Other complaints relate to the lack of protection for intellectual property rights, such as trademarks and patents. Applicable legislation has improved and converged on international standards, but implementation is still inadequate, and foreign investors do not have much confidence in the capacity of the judiciary to protect their rights. 
Table 8.2: Strategic and emerging industries in China (with examples of products/services)

\begin{tabular}{|c|c|c|}
\hline 1. & New energy vehicles & $\begin{array}{l}\text { Electric cars } \\
\text { Battery charging equipment } \\
\text { Hydrogen-powered vehicles }\end{array}$ \\
\hline 2. & Energy efficient and environmental technologies & $\begin{array}{l}\text { Energy-saving technologies } \\
\text { Advanced environmental technology } \\
\text { Recycling }\end{array}$ \\
\hline 3. & Next generation information technology & $\begin{array}{l}\text { Information networks } \\
\text { Advanced electronics } \\
\text { Advanced software and IT services }\end{array}$ \\
\hline 4. & Biotechnology & $\begin{array}{l}\text { Biopharmacology } \\
\text { Biomedical technology } \\
\text { Genetic modification }\end{array}$ \\
\hline 5. & High-end equipment manufacturing & $\begin{array}{l}\text { Aviation industry / components } \\
\text { Satellites and applications } \\
\text { High speed trains / components } \\
\text { Marine equipment }\end{array}$ \\
\hline 6. & New energy & $\begin{array}{l}\text { Nuclear power } \\
\text { Wind power } \\
\text { Solar power }\end{array}$ \\
\hline
\end{tabular}




\begin{tabular}{|ll|}
\hline & Bioenergy \\
\hline $7 . \quad$ New materials & Functional materials \\
& Nanomaterials \\
& High-performance composites \\
\hline
\end{tabular}

Source: "12th Five-Year Plan on National Strategic Emerging Industries", State Council, Beijing, July 2012.

One result of the strong incentives and subsidies in the priority industries is that production capacity can grow very rapidly when innovations reach the market. Subsidized local enterprises-mostly SOEs - tend to expand without much regard for market demand, and the rapid increase in supply may reduce market prices to a level that few profit-maximizing companies can handle. The trend in the wind power industry is a good illustration of this process. By about 2008, more than 100 Chinese manufacturers of wind turbines had entered the national market-the great majority of them owned by various local government authorities-and prices had fallen to a level that in effect forced large multinational companies like Vestas to leave the Chinese market (Liu and Kokko 2010). Few of the Chinese producers covered their costs, but local governments were willing to finance the losses because the central government continued to stress the strategic importance of the wind power sector. The total production capacity of China's wind power industry in 2013 was estimated to be twice as large as domestic demand. The situation in the solar energy industry is similar; the Chinese overcapacity in solar panels has also spilled over into the global market. The European response has been to impose anti-dumping duties on the import of Chinese solar panels. The long-term equilibrium in China obviously cannot be a situation with many local producers and 
continued overcapacity. Instead, it is likely the government will be forced to implement a comprehensive consolidation process, whereby the most efficient local companies will be supported and encouraged to grow through mergers and acquisitions. Such a process has already begun in the automotive industry. The government's vision for that sector is that only a dozen of the more than 100 local brands will survive in the long term, but that these dozen will all operate on such a large scale that they will be able to compete with the established giants in the world market.

More generally, it can be said that the competitive environment for foreign companies in China varies greatly, depending on the strategic importance of the sector and the strength of Chinese companies within it. Foreign firms that are primarily focused on exporting from China and which operate in traditional labour-intensive sectors meet a market-based environment for the most part, where the main challenges relate to changes in the Chinese macro economy. In these sectors, higher labour costs, competition for skilled labour, and concerns about an appreciating renminbi pose bigger threats than does government intervention. In non-strategic industries, market conditions may remain favourable even when the focus is on the domestic market. An example is elder care, where China's needs are growing rapidly but strong domestic companies are lacking. In the retail sector, many foreign companies have been successful-Walmart, Metro, IKEA, Inditex, and H\&M are well-known examples-even if the scope for expansion varies, depending on the product line, the local government setting, and the degree of domestic competition.

High-tech companies in industries where China has long-term ambitions, but not yet much domestic capacity, are welcomed-but they will face major demands for technology transfer. 
In some cases, they will be forced into partnerships with local businesses, and the lack of protection for intellectual property rights will probably become a problem for many of them. Without comprehensive reform of Chinese industrial policy, many of these companies will likely face unequal competition, because emerging Chinese competitors will benefit from public subsidies and other privileges. The development of China's automobile industry is to some extent an example of this. Foreign manufacturers such as Volkswagen, GM, Citroen, and Ford began establishing production in China in the late 1980s, at a time when there was almost no local competition. They were forced into joint ventures with local companies. Over time, these local companies developed their production capacity and increased their market share. Foreign car brands still dominate the Chinese market, but domestic brands have grown rapidly, and today they account for nearly a third of all sales. In 2013, China's auto market was the largest in the world, with total sales of over 17 million cars. In some sectors, however, domestic Chinese capacity remains weak, and strong foreign companies are likely to continue for a long time to dominate the market. Environmental technology is one such area.

Foreign companies in strategically important industries where China has existing production capacity already face unequal competition. In some cases, this takes the form of outright restrictions on entry; in others, local firms enjoy various privileges relating to research, investment, production, and $>><$ procurement-and foreign firms with hard budget constraints find it difficult to survive. As a result, in industries like wind, solar energy, and electric cars, local companies have come to dominate the market. In other sectors, such as telecommunications and information technology, foreign companies like Ericsson face a shrinking market share. It is not in the interest of the central government to force strong foreign players to leave the Chinese market completely, because they play an important role in 
introducing new foreign technology and in disciplining the leading state enterprises (by serving as "benchmarks"). However, the Chinese government does have an incentive to restrict foreign market shares, so as to ensure that "national champions" reach a large enough scale to become competitive outside China as well.

\subsection{The road to more balanced investment conditions}

There is an extensive debate in Europe about how conditions for foreign investors in China and in the EU can be harmonized. As a representative for European companies, the European Chamber of Commerce in China has presented a number of proposals for action which, in principle, call for fundamental reform of the Chinese economy (European Chamber 2013b). In particular, the Chamber of Commerce points to the need for fundamental change in the role of government. Its proposals entail abandoning the investment-driven growth model, liberalizing the financial system, and forcing state enterprises to operate on a level playing field with private companies (both Chinese and foreign). At the same time, the state's role should be reinforced in other areas. For example, its ability to control the economy through transparent and fair rules-rather than through distorting and discriminatory direct interventions-needs to be enhanced. Chinese innovation policy should be reformed. In lieu of a nationalist innovation policy based on discrimination in government procurement and founded on domestic technology standards, catalogues of priority sectors, and mandatory technology transfer requirements, the Chamber of Commerce calls for transparency, equal treatment, and a market-driven approach-in which the state defines the objectives, but leaves their implementation to the business community. In particular, barriers to entry for foreign 
investors must be reduced. The Chamber also notes, very cautiously, that a continued imbalance may make it more difficult for Chinese companies to internationalize in the future.

The cautious warning about possible consequences for Chinese companies operating outside China suggests an alternative approach to addressing the imbalance. It is not realistic to think China is prepared, at least in the short term, to give up its state-controlled economic model because the EU or other international actors put polite demands for fairer investment conditions. More direct and distinct pressure may be required. As long as European investors are subject to discrimination in China, perhaps Chinese investors should not benefit from free access to the European market. Reciprocity rather than imbalance could perhaps be a keyword for relations between the EU and China. Reciprocity would mean access to public procurement in China, reduced barriers to entry to the Chinese market, and stronger protection of the intangible assets that European companies bring to China. Exponents of this somewhat tougher line are mainly to be found in Brussels-in the European Commission and other European institutions.

However, several of the EU's member states prefer to present a softer image in their bilateral discussions with China. This fragmentation among European stakeholders-which stands in stark contrast to the powerful central government in Beijing, which claims a mandate to represent the whole nation-constitutes a further imbalance in the relationship between China and the EU. I will briefly discuss this issue in the next section. First, however, it may be appropriate to reflect on what arguments and instruments Europe can use to demand reciprocity. The answer, from a European perspective, is somewhat dispiriting. The imbalance in volumes of bilateral FDI is still so large that the Union cannot expect to get much by putting 
pressure on Chinese investors in Europe. Bilateral trade volumes, by contrast, are much larger and more important to China, but the prospects for getting the more free trade-oriented EU members to accept the threat of protectionism as a negotiating strategy are not great. One instrument that will still be available for some time stems from the negotiations over Chinese membership in the WTO. Existing members were given the right to consider China a nonmarket economy for a period of 15 years, until 2016. This makes it easier to impose antidumping duties on Chinese exports if they are judged to distort competition in the receiving economy. Many of China's trading partners-especially among developing countries-have formally declared that they now regard China as a market economy, but neither the EU nor the US has taken this step. This leaves some limited room for negotiation, and perhaps even a carrot, to try to convince China of the value of meeting some of the Union's demands. That China's status as a non-market economy is of some importance is demonstrated by the fact that China is the most frequent target of EU anti-dumping duties and safeguards.

Yet, even if various pressures result in a reduction of explicit discrimination in the Chinese market and in fewer formal barriers to entry, it will be difficult to improve conditions for many European companies. The main reason for this is that SOEs dominate most of the sectors where China has strategic interests. Contacts between the state and SOEs are so close that it is difficult to imagine neutral and transparent processes for public procurement. Brødsgaard (2012) describes how leaders of the largest SOEs are appointed by the party, and how they circulate among leadership positions in business, government, and the party. This creates exclusive networks that prevent fair tender processes. In addition, SOEs control a very large part of the business-to-business market. When a state-owned company procures inputs or capital goods-whether it be aircraft, telecommunications systems, power plants, or mining 
equipment-it enters into commercial negotiations with potential sellers. It is difficult and perhaps even impossible to regulate how commercial negotiations are conducted or what kinds of requirements buyers impose on potential sellers. Interviews with representatives of European companies suggest that requirements for local content, technology transfer, specific domestic standards, and the like are already common in such discussions, although in many cases the requirements have been removed from China's explicit industrial policy and trade policy framework.

The issue of "private standards" is not specific to China, and so far China's SOEs have not had much reason to develop such principles. In some areas, in fact, the EU has progressed much further on this front. In the European food industry, for instance, most major wholesalers work with several standards that go beyond the sanitary and phytosanitary requirements specified in the Union's multilateral trade agreements (Carlson and Johansson 2013). Foreign companies would find it very hard to compete in the Chinese market if dominant groups of SOEs were to develop private standards based on local (political) preferences.

It would appear, in sum, that the opportunities to influence Chinese policy-makers are small. It is not realistic to think European pressure can induce China to abandon its state-run development model, so as to create a level playing field for public and private firms and for domestic and foreign companies. Some changes in formal regulatory systems can perhaps be negotiated, but it is unlikely such changes will have any major impact in many of the strategically important sectors, as long as the special status of SOEs persists. Moreover, to achieve any results at all from negotiations, Europe will need to agree on a common China 
policy, and there is no such agreement at present. What else can the EU possibly do in order to deal with the imbalance in investment conditions?

Aside from a strategy that combines the European Chamber's cautious but persistent criticism of distortions in the Chinese business environment with the EU Commission's stricter requirements for reciprocity and its occasional resort to anti-dumping duties, there are at least two additional approaches that could contribute to a slow improvement in this area. One option would be to align more closely with American China policy, which has essentially the same economic objectives as EU policy. The US is stronger than the EU in that it can speak with one voice; but it is also weaker, because its economic imbalances with China are larger and its economy is more dependent on capital inflows from China. A focused effort to align more closely with the US-e.g., through the Transatlantic Trade and Investment Partnership that is currently being negotiated-could change the nature of the game, and to some extent shift the centre of gravity of the global economy from East Asia and the Pacific back to the North Atlantic. A scenario of this kind would give China a stronger incentive to secure its access to the huge North Atlantic market, which in turn would strengthen Europe's bargaining position. I shall return to this scenario in the next section.

An alternative but untested strategy would be for European business to act in a more coordinated way to put pressure on China. Private standards in the food sector relate mainly to health, safety, and the environment. There are also discussions about including operational practices, ethical issues, and labour conditions in these standards. Although requirements of this kind are difficult to justify from an efficiency and free trade perspective, it is likely they would have some impact on producers that are focused on exporting to the EU. Private 
standards, it must be stressed, are not necessarily limited to the food industry, or to matters related to health, safety, or the environment. Most large European companies that have invested in the Chinese market also operate in Europe. They are important customers for Chinese exporters and investors, and they may exert influence through their commercial decisions. Achieving a high level of coordination of European industry vis-à-vis Chinese SOEs is probably impossible; however, if the costs of discrimination in the Chinese market become large enough, there should be some scope to develop joint "private" standards, at least in some sectors (e.g., telecoms or energy). This will be particularly relevant if the Chinese trend towards national standards that favour domestic companies accelerates. It will also be plainly pertinent if the Chinese government cements its practice of replacing formal policy interventions in trade and industry with informal requirements conveyed in commercial negotiations between SOEs and their foreign suppliers. Perhaps it is only by engaging industry and consumers in similar actions that Europe can push through demands for reciprocity.

\section{$4 \quad$ A common European China policy}

In the area of policy-making, the main imbalance between the EU and China lies in the fragmentation of the former. Instead of a common voice and a strong bargaining position based on the fact that Europe is the largest market for Chinese exports, division reigns on the EU side: 28 different countries, each with a weak voice and a small market. The interests of the individual countries differ, and the views of the European Commission rarely represent the average of the national sentiments. Given China's growing importance over the past decade as an export market and investment destination, many of the member countries are reluctant to 
put pressure on China. Strong criticism of China's lack of democracy, human rights, and political opposition is shunned, in order to avoid negative repercussions in the economic area. In addition, China's bargaining position has been strengthened by the European financial crisis, which has led some member states to turn to China for investment and financial support.

However, before the financial crisis sharpened the contrast between northern and southern Europe, there were signs the Union was moving towards a slightly firmer China policy. In their analysis of European attitudes towards China, Fox and Godement (2009) identified four groups of countries with slightly differing perceptions in political and economic terms. On the political dimension, the authors distinguished between countries that were more critical of the Chinese social system and those that were less. On the economic dimension, they focused mainly on the readiness of different countries to use trade policy instruments to influence China. They classified Sweden, Denmark, the Netherlands, and the UK as "Ideological free-traders". Countries in this category were often critical of China's lack of democracy and human rights, and they were prepared to take up sensitive political topics in the bilateral dialogue with China. They were reluctant, however, to use trade policy as a lever to pry open the Chinese market. By contrast, "Assertive industrialists" (Germany, Poland, and the Czech Republic) were also critical of Chinese policy, but willing to use protectionist measures to achieve economic goals. Belgium, Ireland, Austria, Luxembourg, and the Baltic states were "European followers". These countries were similar to the "Ideological free-traders", but they had only limited economic links with China and they were inclined to take a neutral political attitude towards that country. They were perceived as the most willing to follow a common EU policy. "Accommodating mercantilists", the largest group, included almost all of the southern and eastern member states of the Union. Many of these countries were willing to use trade 
barriers to protect their own markets, but they did not perceive any need for a political confrontation with China. They preferred a more accommodating political attitude, in order to facilitate economic interchange with China-even in cases where the Commission decided that it was necessary to protect European industry with anti-dumping duties or other interventions. France fell outside these groups. According to Fox and Godement (2009), France was a highly typical "Accommodating mercantilist" under Chirac until 2007. The authors were unable, however, to categorize Sarkozy's government, due to its unpredictable blend of political support for China with tough criticism of that country for its lack of democracy, the situation in Tibet, and so on.

Despite these differences of opinion, there were signs of some degree of increasing coordination of EU China policy during the 2005-2010 period. At the political level, the EU seemed to be prepared to put more pressure on China. European criticism of the human rights situation in that country became more vocal when Sarkozy chose to meet with the Dalai Lama during France's EU presidency in 2008, and when the EU refused to abolish the arms embargo that had been imposed after the Tiananmen Square events (despite repeated Chinese demands to that effect in 2005-2008). The Union also took a tougher stance in the economic area. As China's economy expanded and Chinese companies grew increasingly competitive, the economic imbalance-in terms of both trade and unequal conditions for FDI-seemed less and less acceptable. The Commission's demands for reciprocity and equal treatment grew stronger, and a clearer connection was made between the EU's need for better access to China's market and a possible decision on its part to award market economy status to that country. 
The Union's tougher stance in turn affected Chinese attitudes towards cooperation with Europe. Before the global financial crisis, China was concerned that its dependence on Europe was (or at any rate appeared to be) greater than Europe's dependence on it. The EU had a big deficit in its bilateral trade account with China, but its global deficit was not large. The Union's tougher attitude put China in a difficult position. Instead of playing with large stakes and aiming at a comprehensive strategic partnership with the EU-with the compromises and concessions that such would require-China chose a combination of two other strategies. On the one hand, it emphasized its relationship with the United States. A G2 arrangement suited China, because its negotiating position under such conditions was strong. Granted, the US deficit was larger than the European one, and that could have led to tough demands for import restrictions from the American side; however, the US was also dependent on China to finance its deficits. The US also had much more FDI in China than Europe did, adding to China's bargaining power. The US-China relationship too has required compromises-the appreciation of the RMB in recent years is to some extent a result of US pressure-but the outcome has been easier to predict.

On the other hand, China's relationship with the EU shifted towards bilateral contacts. China signalled its reaction to the tougher EU position already at an early stage, as when it cancelled a planned China-EU summit after Sarkozy's meeting with the Dalai Lama in 2008, and after European criticism of the lack of human rights in China. Already before that time, in fact, China had begun to shift its focus from contacts with the EU institutions towards deeper relations with individual EU countries. One reason for this, most probably, was that China had concluded it would be more appropriate to treat the EU as a confederation than as a federation-at any rate for the foreseeable future. The financial crisis that hit the EU in 2008 
confirmed this strategy, since-as we shall see below-it created a demand for precisely the type of bilateral relations that China was interested in.

Godement and Parello-Plesner (2011) note that China has built up its bilateral relations with countries in Africa by entering on a broad front, with investments in transport infrastructure, manufacturing, logistics, and retail trade, coupled with investment and trade credits and diplomatic initiatives. This has benefited China's African partner countries by creating opportunities for growth, but it has also given China a good strategic position that allows it to benefit from and to control future development. Since the outbreak of the financial crisis, China has started applying a similar strategy in its bilateral relations with countries in southern and eastern Europe, promising FDI as well as financial support to several of the EU members struggling with deficits in government budgets and in current accounts. Hence, in and around 2010, southern and eastern Europe attracted 40 percent of the inflow of Chinese FDI into the $\mathrm{EU}$, which is a disproportionately large share considering the size of the economies in question. China was also reported to have bought government bonds from countries such as Greece, Cyprus, Portugal, Spain, and Ireland. There are no official statistics on Chinese bond purchases, however, and it is hard to assess the significance of these actions.

Meanwhile, China has also tried to establish special relationships with some of the EU members that have been more critical towards China. Its relationship with Germany has been particularly important. There are several reasons for China to seek closer cooperation with Germany. Not only does the latter country have Europe's strongest economy; its dominance has also grown, as a consequence of the financial crisis. There are also important complementarities between the two countries: Germany needs the Chinese market for its 
export industry, while China needs German technology for its industrial development. It is therefore not surprising that the Chinese market has become more important for German industry. Growing exports to China have helped dampen the impact of the financial crisis on Germany. China is already the largest export market for the automotive and manufacturing industries in that country, and it is an important destination for German direct investment (DB Research 2013). On the political front, China has upgraded its relationship with Germany to a strategic partnership. This includes annual consultations between the heads of government, which have taken place even when summits between the EU and China have been cancelled because of increased political tensions. As a result, German leaders have toned down their political criticism of China, and focused instead on economic cooperation. The German motto "Wandel durch Handel" (development through trade) reflects the expectation that trade and economic interchange will promote social transformation (Kundnani and Parello-Plesner 2012).

Having Germany as a strategic partner is of great value to China-and not just where relations with the EU are concerned, but in a larger context as well. The discussions that took place in lead-up to the G20 Summit in 2010 were an illustration of this. It was proposed that no country (read: China) should be allowed to have a current account surplus in excess of 4 percent of GDP. Both China and Germany protested sharply, and the proposal was put aside. It should be noted that Germany's current account surplus (as a share of GDP) has been notably higher than China's in recent years-at around 6 percent, as against China's surplus of 2-4 percent. More remarkably still, Germany's surplus in US dollars was of the same magnitude as China's in 2011 and 2012. 
China's changing attitude towards the EU has resulted both in a clearer division of labour between the EU institutions and the individual member states, and in a polarization among the latter regarding attitudes towards China. China's growing economic weight means that few member countries think they can afford to take a strong ideological stance vis-à-vis that country. Most prefer a more conciliatory approach, in order to avoid losing Chinese investment and loans. The responsibility for taking a more critical line is therefore transferred to the EU institutions. Where member states' attitudes are concerned, Godement and ParelloPlesner (2011) argue that the four country categories identified by Fox and Godement (2009) have now collapsed into two main groups. The political dimension by which the countries are classified (the degree of criticism of China) is unchanged. The economic dimension, however, has evolved. Countries that are primarily interested in China's markets are contrasted with those that prioritize the opportunities offered by the inflow of Chinese investment and credits. The first country group-“Frustrated market-openers"-consists of Sweden, Denmark, the Netherlands, and the UK, with Germany and France as new allies. These countries, which had been "Ideological free-traders" before (Germany and France excepted), are still reluctant to use protectionist tools to pry open the Chinese market, but they now seem prepared to accept the use of the term reciprocity, as well as a resort to the threat of trade barriers in negotiations. (Despite its strategic partnership with China, Germany seems prepared to use the EU institutions to put pressure on China.) This more activist group is balanced by the southern European countries, which, together with Hungary, Romania, and Bulgaria, see China as a part of the solution to their financial problems. These countries make up the group "Cashstrapped deal-seekers". Their short-term interest lies not in selling to the Chinese market, but in attracting Chinese investors. The majority of member states in central and eastern Europe, 
along with such countries as Ireland, Belgium, and Luxembourg, are found between these two groups. They hope to attract some inflows of Chinese capital, but they take a more critical attitude towards China than do the "Cash-strapped deal-seekers".

It is obvious the EU faces a major challenge in formulating a common China policy. The differences in national strategy vis-à-vis China are not just connected with political considerations; they also reflect fundamental differences in economic structure. Countries like Germany see opportunities in the Chinese market, and they have been successful in adapting to China's global expansion. By moving away from industries in which China is more competitive and expanding in areas where Chinese demand is high (and where China's technical skills have not caught up with Europe's), Germany has managed to maintain exports as a key driver of its economy. Other countries, particularly in southern Europe, have been unable to adapt to China's expansion, and so have been defeated by Chinese exporters in many of their traditional export industries.

Figure 8.7 points to one of the fundamental reasons for these structural differences. Insufficient investment in R\&D made it impossible for countries such as Greece, Portugal, Spain, and Italy to upgrade production or to build up new export industries when China began cutting into their market shares. The opposite was true for countries such as Germany and Sweden, where investment in R\&D led to innovations that contributed to large current account surpluses some years later. This suggests the debt problems in the PIIGS countries were caused not only by excessive borrowing and undisciplined financial management, but also by insufficient adaptation to China's global expansion. 
Nor will these fundamental differences automatically disappear when the acute debt problems are resolved. It is likely, rather, that the contrast between southern and northern Europe will persist. It is even possible the asymmetries in macroeconomic flexibility and adaptability will increase, since much of the crisis management carried out in the most severely affected EU economies has taken the form of budget cuts and reduced public investment. Some of the budget cuts, it seems, are affecting precisely the areas which are central for enhancing future competitiveness and structural adaptability: R\&D and higher education. As a result, much of the adjustment to increased foreign competition in these countries will have to take place through lower labour costs rather than higher labour productivity.

Figure 8.7: R\&D expenditures in 2000 and current account balances in 2008, EU-15.

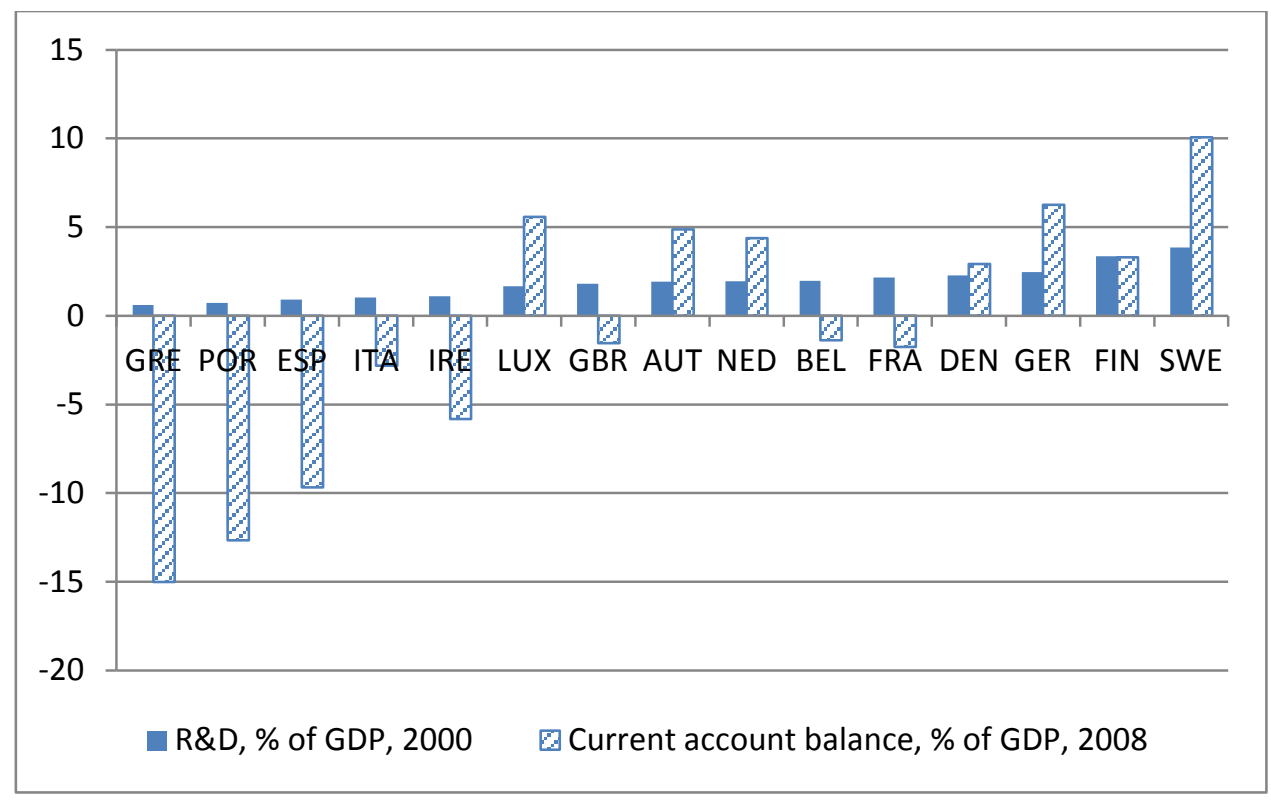

Source: World Bank Databank. 
The prospects for a unified European policy towards China are therefore not very good. The interests of individual member states towards China vary, and they vary too greatly for a reconciliation between them to be possible in the short term. If southern and eastern Europe are to be persuaded to join with western and northern Europe in a common approach to China, then far-reaching reforms in internal EU policy will likely be necessary. The Union will have to provide enough internally generated resources (subsidies and credits) to compensate for the expected loss of credits and investment from China. The probability of this happening in the current institutional environment is low. Granted, Chinese labour costs are expected to rise so rapidly as to induce some production to move back to Europe from China quite soon; however, the volume of returning investment is unlikely to be large enough to make any major difference. It may instead make more sense to place our hopes in closer cooperation with the United States, through the establishment of a transatlantic free trade and investment partnership. A TTIP is expected to create hundreds of thousands of new jobs in both Europe and North America, and to strengthen the negotiating position of both regions in their dialogue with China.

However, whether a transatlantic agreement can be reached or not, it is clear that it lies in the common European interest that dependence on China not grow too great. The most realistic scenario for a European China policy is that the division of labour between the EU institutions and the individual member states remains in place. This entails a central role for the EU in demanding reciprocity and working for greater market access to China, in some cases with European trade policy as an instrument. The Union may also take on a stronger role than before in order to make sure Chinese investment in Europe does not distort or undermine 
labour laws or tax laws in the single market. By delegating the critical and scrutinizing role to the EU institutions, member states with urgent needs and a weak bargaining position can avoid bilateral discussions in which they are forced to make far-reaching compromises on subsidies, labour regulations, the environment, and other areas that ought to be governed by common EU rules. How well such a multi-pronged strategy works will naturally depend on whether a more critical EU attitude is supported by the member countries. Germany's attitude is particularly important, given both its economic weight and the fact that China has decided to invest specially in relations with it.

\section{$5 \quad$ A transatlantic partnership to balance China}

In this paper, I have discussed three imbalances that weigh on the relationship between the EU and China. The large deficit in Europe's trade with China is the first. The EU is China's biggest export destination, and in recent years China's bilateral trade surplus with the EU has been almost as big as its surplus with the US. China's global expansion has particularly created problems for EU countries which export relatively labour-intensive goods in mature industries, in direct competition with China.

The second imbalance concerns conditions for European investment in China and Chinese investment in Europe. There is an asymmetry in terms of investment flows-EU investment in China is ten times larger than Chinese investment in the EU-but this imbalance has begun to diminish slowly, as Chinese companies internationalize. The imbalance which remains in this area is that between the business environment for foreign investors in the $\mathrm{EU}$ and that for foreign investors in China. While Chinese companies have essentially free access to the 
European market, including the market for public procurement, foreign companies operating in the Chinese market face significant barriers.

The third imbalance in the relationship between the EU and China stems from the EU's inability to agree on a common stance vis-à-vis China. While China has a strong central government which can implement policies that maximize benefits for the nation as a whole, the EU is fragmented. It has no common China policy. Instead it has a relatively weak EU Commission, which is trying to pursue its policy goals at the same time that several member states are pursuing national strategies to achieve mainly domestic objectives, rather than the interests of the Union as a whole.

I argued above that some of the imbalances in the trade area will gradually diminish. China's wage levels are expected to rise rapidly in coming years, for demographic and structural reasons, and this will help gradually to eliminate China's "unfair" competitiveness in international trade. However, many imbalances relating to investment conditions are unlikely to disappear in the near future. Remaining market access restrictions and discriminatory practices are likely to survive, especially in strategic sectors where China seeks to build up its future competitiveness. In the short term, the EU does not have the means to influence the Chinese business environment-particularly the special relationship between the state and state-owned enterprises. The Union's fragmentation is one major reason for this. The countries that would like the Union to present a tougher policy front to China do not have the desire (or ability) to compensate those EU members that are afraid a tougher China policy will be costly in terms of foregone Chinese investment and credits. China, for its part, does not necessarily perceive the fragmentation of European interests as a disadvantage. It may find it 
easier, namely, to reach its policy objectives if it can "divide and conquer", by focusing on bilateral dealings with individual EU countries instead of negotiating with a unified and powerful EU Commission.

Over the medium term, however, there may be cause for greater optimism about the EU's ability to influence China, and to obtain better conditions for European investors in the Chinese market. The Union has two weaknesses in its current relationship with China. One is that a stagnant EU probably needs stimulus from its relationship with China to a greater extent than China needs anything from the EU. The second is that structural imbalances within the EU itself prevent it from achieving a strong negotiating position, because different countries within it have fundamentally different interests. Both of these deficiencies might, however, be mitigated by one and the same process. The Transatlantic Trade and Investment Partnership (TTIP) currently being prepared between the US and the EU can help make the European market more attractive to the outside world, and facilitate recovery in those parts of Europe that today see China as one of the few sources of investment and credits. A large transatlantic market will be so attractive as to enable the EU and the US to pressure China jointly for reform and reciprocity. It will also create an alternative to investment and financing from China, and facilitate the development of a common European China policy. Of course, a transatlantic partnership is attractive for Europe even without these advantages. When the indirect effects on relations between the EU and China (and the US and China) are included besides, it becomes well-nigh irresistible. 


\section{References}

Brødsgaard, K.E. (2012), "Politics and Business Group Formation in China: The Party in Control?", The China Quarterly, 211(3): 624-648.

Cai, F. (2010), "Demographic Transition, Demographic Dividend, and Lewis Turning Point in China", China Economic Journal, 3(2): 107-119.

Carlsson, C. and H. Johansson (2013), "Private Standards-Levelling the Playing Field for Global Competition in the Food Supply Chain", Rapport 2013:2, AgriFood Economics Centre, Lund.

DB Research (2013), "German Industry: China Market Growing Moderately", Research Briefing, Deutsche Bank Research, Frankfurt.

Dunning, J.H., C. Kim and D. Park (2008), “Old Wine in New Bottles: A Comparison of EmergingMarket TNCs Today and Developed-Country TNCs Thirty Years Ago", in K.P. Sauvant (ed.), The Rise of Transnational Corporations from Emerging Markets: Threat or Opportunity? Edward Elgar, Cheltenham.

Ernst \& Young (2012), “China Going Global. The Experiences of Chinese Enterprises in the Netherlands", Ernst \& Young, Amsterdam.

European Chamber (2013a), "Chinese Outbound Investment in the European Union", European Union Chamber of Commerce in China, Beijing.

European Chamber (2013b), "European Business in China: Position Paper 2013/2014", European Union Chamber of Commerce in China, Beijing.

Fox, J. and F. Godement (2009), "A Power Audit of EU-China Relations", Policy Report, European Council on Foreign Relations, London.

Godement, F. and J. Parello-Plesner (2011), "The Scramble for Europe", Policy Brief, European Council on Foreign Relations, London. 
Hanemann, T. and D.H. Rosen (2012), "China Invests in Europe: Patterns, Impacts and Policy Implications", Rhodium Group, New York.

Kokko, A. and Y. Liu (2012), “Governance of New Energy Vehicle Technology in China: The Case of Hybrid Electric Vehicles", in M. Nilsson, K. Hillman, A. Rickne, and T. Magnusson (eds.), Paving the Road to Sustainable Transport: Governance and Innovation in LowCarbon Vehicles, Routledge, London.

Kundnani, H. and J. Parello-Plesner (2012), "China and Germany: Why the Emerging Special Relationship Matters for Europe", Policy Brief, European Council on Foreign Relations, London.

Liu, Y. and A. Kokko (2010), "Wind Power in China: Development and Policy", Energy Policy, 38(10): 5520-5529.

Nicolas, F. (2009), "Chinese Direct Investment in Europe: Facts and Fallacies", International Economics Briefing Paper 2009/01, Chatham House.

Zhu, A. and W. Cai (2012), "The Lewis Turning Point in China and Its Impact on the World Economy", Augur Working Paper, Tsinghua University, Beijing. 


\section{COPENHAGEN DISCUSSION PAPERS}

2005:

2005-1 May: Can-Seng Ooi - Orientalists Imaginations and Touristification of Museums: Experiences from Singapore

2005-2 June: Verner Worm, Xiaojun Xu, and Jai B. P. Sinha - Moderating Effects of Culture in Transfer of Knowledge: A Case of Danish Multinationals and their Subsidiaries in P. R. China and India

2005-3 June: Peter Wad - Global Challenges and Local Responses: Trade Unions in the Korean and Malaysian Auto Industries

2005-4 November: Lenore Lyons - Making Citizen Babies for Papa: Feminist Responses to Reproductive Policy in Singapore

2006:

2006-5 April: Juliette Koning - On Being "Chinese Overseas": the Case of Chinese Indonesian Entrepreneurs

2006-6 April: Mads Holst Jensen - Serve the People! Corporate Social Responsibility (CSR) in China

2006-7 April: Edmund Terence Gomez - Malaysian Investments in China:

Transnationalism and the 'Chineseness' of Enterprise Development

2006-8 April: Kate Hannan - China's Trade Relations with the US and the EU WTO Membership, Free Markets (?), Agricultural Subsidies and Clothing, Textile and Footwear Quotas

2006-9 May: Can- Seng Ooi - Tales From Two Countries: The Place Branding of Denmark and Singapore

2006-10 May: Gordon C. K. Cheung - Identity: In Searching the Meaning of Chineseness in Greater China

2006-11 May: Heidi Dahles - 'Chineseness' as a Competitive Disadvantage, Singapore Chinese business strategies after failing in China

2006-12 June: Émile Kok- Kheng Yeoh - Development Policy, Demographic Diversity and Interregional Disparities in China 
2006-13 June: Johannes Dragsbaek Schmidt - China's "soft power" re-emergence in Southeast Asia

2006-14 September: Michael Jacobsen - Beyond Chinese Capitalism: Re-

Conceptualising Notions of Chinese-ness in a Southeast Asian Business cum Societal Context

2006-15 October: Ng Beoy Kui - The Economic Rise of China: Its Threats and Opportunities from the Perspective of Southeast Asia

2007:

2007-16 February: Michael Jacobsen - Navigating between Disaggregating Nation States and Entrenching Processes of Globalisation: Reconceptualising the Chinese Diaspora in Southeast Asia

2007-17 April: Émile Kok-Kheng Yeoh, Shuat-Mei Ooi - China-ASEAN Free Trade Area: Implications for Sino-Malaysian Economic Relations

2007-18 May: John Ravenhill, Yang Jiang - China's Move to Preferential Trading: An Extension of Chinese Network Power?

2007-19 May: Peter J. Peverelli - Port of Rotterdam in Chinese Eyes

2007-20 June: Chengxin Pan - What is Chinese about Chinese Business? Implications for U.S. Responses to China's Rise

2007-21 September: Charles S. Costello III - The Irony of the Crane: Labour Issues in the Construction Industry in the New China

2007-22 October: Evelyn Devadason - Malaysia-China Network Trade: A Note on Product Upgrading

2007-23 October: LooSee Beh - Administrative Reform: Issues of Ethics and Governance in Malaysia and China

2007-24 November: Zhao Hong - China- U.S. Oil Rivalry in Africa

2008:

2008-25 January: Émile Kok-Kheng Yeoh - Ethnoregional Disparities, Fiscal Decentralization and Political Transition: The case of China

2008-26 February: Ng Beoy Kui - The Economic Emergence of China: Strategic Policy Implications for Southeast Asia

2008-27 September: Verner Worm - Chinese Personality: Center in a Network 
2009:

2009-28 July: Xin Li, Verner Worm - Building China's soft power for a peaceful rise

2009-29 July: Xin Li, Kjeld Erik Brødsgaard, Michael Jacobsen - Redefining Beijing Consensus: Ten general principles

2009-30 August: Michael Jacobsen - Frozen Identities. Inter-Ethnic Relations and Economic Development in Penang, Malaysia

2010:

2010-31 January: David Shambaugh - Reforming China's Diplomacy

2010-32 March: Koen Rutten - Social Welfare in China: The role of equity in the transition from egalitarianism to capitalism

2010-33 March: Khoo Cheok Sin - The Success Stories of Malaysian SMEs in Promoting and Penetrating Global Markets through Business Competitiveness Strategies

2010-34 October: Rasmus Gjedssø and Steffen Møller - The Soft Power of American Missionary Universities in China and of their Legacies: Yenching University, St. John's University and Yale in China

2010-35 November: Michael Jacobsen - Interdependency versus Notions of Decoupling in a Globalising World: Assessing the Impact of Global Economics on Industrial Developments and Inter-Ethnic Relations in Penang, Malaysia

2010-36 November: Kjeld Erik Brødsgaard - Chinese-Danish Relations: The Collapse of a special Relationship

\section{1:}

2011-37 April: Masatoshi Fujiwara - Innovation by Defining Failures under Environmental and Competitive Pressures: A Case Study of the Laundry Detergent Market in Japan

2011-38 November: Kjeld Erik Brødsgaard - Western Transitology and Chinese Reality: Some Preliminary Thoughts

2012:

2012-39 December: Kjeld Erik Brødsgaard - Murder, Sex, Corruption: Will China Continue to Hold Together? 
2013:

2013-40 January: Sudipta Bhattacharyya, Mathew Abraham and Anthony P. D'Costa Political Economy of Agrarian Crisis and Slow Industrialization in India

2013-41 February: Yangfeng Cao, Kai Zhang and Wenhao Luo - What are the Sources of Leader Charisma? An Inductive Study from China

2013-42 April: Yangfeng Cao, Peter Ping Li, Peter Skat-Rørdam - Entrepreneurial Aspiration and Flexibility of Small and Medium-Sized Firms: How Headquarters Facilitate Business Model Innovation at the Subsidiary Level

2013-43 October: Zhiqian YU, Ning ZHU, Yuan ZHENG - Efficiency of Public Educational Expenditure in China

2013-44: November: Yangfeng Cao - Initiative-taking, Improvisational Capability, and Business Model Innovation in Emerging Markets

2014:

2014-45 January: Michael Jakobsen - International Business Studies and the Imperative of Context. Exploring the 'Black Whole' in Institutional Theory

2014-46 February: Xin Li - The hidden secrets of the Yin-Yang symbol

2015:

2015-47 March: Aradhna Aggarwal and Takahiro Sato - Identifying High Growth Firms in India: An Alternative Approach

2015-48 May: Michael Jakobsen - Exploring Key External and Internal Factors Affecting State Performance in Southeast Asia

2015-49 May: Xin Li, Peihong Xie and Verner Worm - Solutions to Organizational Paradox: A Philosophical Perspective

2015-50 June: Ari Kokko - Imbalances between the European Union and China 